\title{
Beastly Beatitudes (1): The Case of A Patient with Severe Borderline Personality Disorder
}

\author{
Paul D. Zislis, MD \\ University of North Carolina at Chapel Hill
}

Follow this and additional works at: https://jdc.jefferson.edu/jeffjpsychiatry

Part of the Psychiatry Commons

Let us know how access to this document benefits you

\section{Recommended Citation}

Zislis, MD, Paul D. (1987) "Beastly Beatitudes (1): The Case of A Patient with Severe Borderline Personality Disorder," Jefferson Journal of Psychiatry. Vol. 5 : Iss. 2 , Article 7.

DOI: https://doi.org/10.29046/JJP.005.2.004

Available at: https://jdc.jefferson.edu/jeffjpsychiatry/vol5/iss2/7

This Article is brought to you for free and open access by the Jefferson Digital Commons. The Jefferson Digital Commons is a service of Thomas Jefferson University's Center for Teaching and Learning (CTL). The Commons is a showcase for Jefferson books and journals, peer-reviewed scholarly publications, unique historical collections from the University archives, and teaching tools. The Jefferson Digital Commons allows researchers and interested readers anywhere in the world to learn about and keep up to date with Jefferson scholarship. This article has been accepted for inclusion in Jefferson Journal of Psychiatry by an authorized administrator of the Jefferson Digital Commons. For more information, please contact: JeffersonDigitalCommons@jefferson.edu. 


\title{
Beastly Beatitudes (1): The Case Of A Patient With Severe Borderline Personality Disorder
}

\author{
Paul D. Zislis, M.D.
}

The newspapers, tabloids, and novels are filled with it. So are the television shows and movies. Sensationalism. The public can't get enough of it. A crazed killer stalks an innocent victim who is alone, isolated and helpless, and he brutally tortures her to death. Sound familiar? The case at hand is a fascinating one which, though perhaps surrounded by the trappings of such sensationalism, provides us with some insight into the inner workings of one patient's tortured mind.

\section{THE CASE}

The patient is a 23 year old single white male who presented for the first time to his local mental health center. He was a recent college graduate who had just moved to the area to begin work in a small accounting firm. His chief complaint was insomnia of five years duration. He stated that the insomnia was due to feelings of guilt and anxiety; the reasons for these feelings he could not identify. There was no history of any previous psychiatric contact. He began psychotherapy with a clinically experienced psychiatrist. Within two months he was hospitalized for nearly a three month period after having grown increasingly depressed and suicidal and having begun to cut himself with a razor. $\mathrm{He}$ was diagnosed as having Major Depression and Borderline Personality Disorder. Following the hospitalization, he continued with depressive symptoms, began drinking heavily, was intermittantly anorexic and bulimic, continued cutting himself superficially and once made a suicidal gesture. Over the next ten months he was hospitalized on two more occasions and was treated with therapeutic doses of a variety of psychotropic medications, including tricyclic and MAOI antidepressants, lithium and both high and low potency neuroleptics.

He began to limit his self-destructive activity and started to reveal information about his past in outpatient therapy. However, he soon experienced renewed insomnia and one day related to his therapist that the previous night he had gone for a walk to test out a fantasy he had been having. He approached an attractive young woman walking in a dark, isolated area and asked her for

Dr. Zislis is a fourth-year resident at the University of North Carolina at Chapel Hill. 
directions. The fantasy was that he would distract her attention with a question, knock her unconscious and then proceed to severely mutilate her body, particularly her sexual organs, with the razor blade that was in his pocket. However, after an exchange of words lasting ten seconds, he and the woman parted. The patient revealed that he had had this fantasy for some time and felt increasingly compelled to act out on it, to make it a reality. He was distraught that he had actually gone this far in bringing the fantasy to life, but felt as though he would be unable to control the forces that drove him to perform these acts. He was immediately hospitalized, and it was at that point that this writer was introduced to the patient, as it was felt that his previous therapist, a woman, was at too great a risk to her own safety to continue working with him. His initial response to the change in therapists was one of feeling rejected, abandoned and filled with a sense of rage.

The patient was a man of intense appearance, with a face that revealed internal torment. He was highly anxious and rarely made eye contact. Somewhat disarming was the fact that he spoke with a quiet and articulate voice. He revealed a very unusual pattern of mostly well healed, generally superficial scars, each measuring about eight inches in length, which were present in clusters on his forearms, shoulders, chest, abdomen and legs, and which were caused by self-induced lacerations made by razor blades or paper clips. He had been cutting himself, it turned out, since age 13. He stated that at times he hated to see the wounds heal and disappear, for he felt the wounds had an identity and life of their own, and their disappearance was their response to his not paying enough attention to them (by keeping them open and bleeding) and represented their abandonment of him.

He related that his self-lacerating was done not in a brief and slashing moment of anger, but with well defined purpose, attention and care. There was a ritual to it. He would cut himself on days when he felt initial hopefulness followed by self-doubt, disappointment, sense of failure, depression, guilt, abandonment and loneliness. This would progress to a sense of fear and panic, a sense that he was peering out at the world from a belljar, a sense that the walls of rooms, buildings and other inanimate objects such as laundry were becoming personified, and with menacing, hostile intentions, were creeping up on him to overwhelm him. He would then begin to feel as though he were losing control, losing his mind and even his body - that his body was disintegrating and disappearing into the universe. This caused increasing panic and a sense that he had to recapture himself by some means to prevent himself from disappearing. The organizing and unifying act that he came upon was that of slowly etching a long linear cut into his skin. It would bring his body and mind back together. It would give him himself again. He described looking forward to cutting himself with a sense of anticipation. The act of cutting was filled with excitement, and it was followed by a release of tension and sense of relief, calm, fulfillment and satisfaction. 
In considering this patient, there are two questions to be addressed: What was behind this bizarre thinking and what would the treatment be? The latter question was approached first. He was clinically depressed. Additionally, although his thought process was intact and he consistently denied any hallucinations, he was highly anxious and agitated and his thought content was highly disordered with marked bizarre delusions of a paranoid quality. He also was consumed by grotesquely violent homicidal fantasies. Laboratory workup revealed no organic basis for his psychiatric symptoms. Therefore, fairly aggressive neuroleptic treatment was begun; thioridazine was initiated at 300 $\mathrm{mg} /$ day. In addition, the antidepressant which he had been on prior to this hospitalization, phenelzine, was increased from $60 \mathrm{mg} /$ day to $75 \mathrm{mg} /$ day. He responded to this course of therapy surprisingly quickly and was discharged from the hospital within four weeks of admission. In the first four months following his discharge, he never developed a return of the violent fantasies, at least not to the point where he felt like acting on them, and he was able to abstain from cutting himself. He did, however, continually experience recurrence of sleeplessness, depressed mood, anxiety, derealization, depersonalization and existential angst with feelings of panic and loss of control. Medication management became a course of chasing after these symptoms by increasing the dosage of his neuroleptic every one to two weeks with each new exacerbation, which would contain and relieve his symptoms for a while, but which he continually broke through. After reaching a ceiling of $800 \mathrm{mg} /$ day of thioridazine, this was discontinued and chlorpromazine, up to $1400 \mathrm{mg} /$ day, was prescribed. Finally, in a week which saw the simultaneous occurence of a number of events, including a planned vacation for his therapist, the anniversary of his father's death and the anniversary of his suicide attempt, he again became symptomatic with a return of fantasies and his fears of acting out on them, as well as return of self-cutting; he was rehospitalized for his fifth time in seventeen months. During this hospitalization, the patient underwent a course of ECT with successful results. In fact, he had been hospitalized for some time prior to ECT treatment and had actually begun to improve prior to ECT initiation, thus making the role of the ECT treatment in his recovery unclear. He was discharged on desipramine, $150 \mathrm{mg} /$ day, and he returned to his family home in another state.

What was behind this unusual presentation in this young man who was tortured even by his fantasies of torture? The initial course of psychotherapy concentrated not on exploring the workings behind his fragile and fragmented ego, but rather on attempting to build a foundation for ego function by strengthening his coping skills needed for here and now issues, as he had essentially been unable to function productively for more than a year. Given his ego weaknesses and his susceptibility to decompensate to the point of psychosis, he could not have tolerated a more indepth examination of the painful memories of his history while he was an outpatient. Yet during his last hospitalization it seemed necessary to uncover this background if any true 
progress were to be made, and the hospital provided the protective environment to be able to do so. What was learned will be reviewed in the following section.

\section{ANALYSIS OF THE KEY PSYCHODYNAMIC ISSUES}

The developmental and family dynamics were intriguing contributors to his psychopathology. In brief, the patient's mother was highly labile emotionally. He found her threatening and overwhelming. She inspired feelings of guilt and unworthiness in the patient, yet she was also dependent on him and discouraged his separation, growth and independence. His father was emotionally distant and detached; an academician who died in a motor vehicle accident when the patient was 12 . The patient idealized him yet he never really grieved his loss and felt guilty for this. This patient described himself as being a loner as a child. He had one trusted friend who was several years older than the patient. When the patient was 13 and his friend was 15, the friend one day took the patient by surprise and violently raped him. It was following this event that the patient first began to have the fantasy of the sexual slaying and also soon after began to cut himself. When the patient was 16 , he went to a party and was coerced by friends to have sex with a girl his same age. Like his only previous sexual contact, he found this experience degrading and humiliating. He never had another sexual encounter. The patient was an honors student in college and worked as a fast food attendant to pay for his college tuition. On occasion he fantasized about taking hostages at work, killing them and being killed himself by police. He occasionally used marijuana, cocaine and alcohol. He lived at his family home throughout college. It was only upon leaving home for the first time when he began work as an accountant that the chronic anxiety he experienced mounted into a sense of panic, the fantasies of torture became obsessional, the cutting ritual became compulsive and he began to fear losing all control.

In assessing the relationship of the significant events in the patient's history to his clinical presentation, it is clear that the patient started from a developmental base of fear of his mother and absence of an emotionally fulfilling relationship with his father, with consequent difficulty in being able to trust and form attachments to others. When this trust and attachment was at last established with his childhood friend, it was betrayed in the brutal violation of rape. Ever since that violation, the patient felt not only rage towards his friend, but also a sense of guilt, a feeling that somehow he was responsible for the event. These were similar to the feelings of guilt which his mother had engendered; that he must somehow be responsible for her hostile behavior towards him. Also, during the period of his life when the rape occurred, the patient was entering puberty and feeling a sexual attraction towards females. But he had received a Catholic upbringing and had taken from it a lesson about the evils of sexual desire. This, combined with his experience of sexual assault established in him the belief that sex was cruel, evil and dirty. In the patient's opinion, the one 
failing of his (idealized) father was that he had sexual relations with his mother. The patient stated that a truly good man, a man with the attributes of a saint, does not have sexual desires or partake in sex. The patient's life goal was to be a good human being, one who gave totally of himself for the betterment of mankind; in essence, to be a saint. The patient related that during his only heterosexual encounter, which he was coerced into by both his friends and his sexual partner, he also felt responsible and guilty. There was no vaginal intercourse because of the partner's fear of pregnancy, but there was oral and anal intercourse at her insistence. Although the patient was not victimized in this event as he had been during his homosexual rape, he still identified with his role of victim, with flashbacks to the first event during the second. Additionally, because of his role in the anal intercourse, he also identified himself with his previous tormentor, a role unacceptable to his ideal of saintliness and which further stimulated his rage. Thus for the patient, sexual desires were evil, as were positions used in sex which made one both a victim and a tormentor. Flashbacks to both sexual encounters occurred during his fantasies of slayings.

His recourse to that which prevented him from being the "saint" he wished to be was, through fantasy, to eliminate those who stimulated his intolerable "immoral" sexual desires and to do so in a way which would punish them in the process, specifically by the violent removal of the parts of their bodies that taunted him. This fantasy also represented a displacement of the aggressive impulses he had against mother, for not only had his mother "destroyed" him, but she had also "destroyed" his otherwise perfect father by being a source of sexual desire for him. His highly active superego, however, recognizing that a saint does not punish and murder others, caused him even greater torment, which he handled by turning these unacceptable fantasy impulses towards others against himself, thus turning the idea of cutting others into one of cutting himself. This was at least an acceptable drive, for inflicting punishment on himself to spare the suffering of others was further testimony to his saintly intentions. Thus for the patient, the act of cutting himself was not one of rage or hate of self or others (though one could argue that ultimately, such an act always is), but rather one of love and caring, of giving to others, of being a saint.

When this overwhelming conflict between "good" and "evil" reached psychotic proportions, buildings, rooms (and even laundry), where he had been trapped before during his two sexual experiences, became hostile reminders of the memories he tried to supress, They further progressed to personifications of his own projected hostile impulses. He perceived this process as though he were losing his own physical integrity and melding into an identity with them. They were now a representation of a hostile universe, one which simultaneously both stemmed from and was directed against him. Similarly, the wounds and scars which represented his denial of unacceptable impulses and his identification with goodness would become personified, and when healed and disappearing, would cause him to feel guilty, as though they had abandoned him for his not being attentive enough to them. This appears to represent a symbolization of 
abandonment of him by the loving mother he never had but always wished for, the mother who demanded his attention and made him feel guilty and responsible for the disappearance of her love.

\section{DISCUSSION}

First, a word about transference and countertransference issues is in order. A patient as provocative as the individual described in this case is bound both to have strong feelings concerning the therapeutic relationship and to evoke strong feelings in the therapist.

Although the transference was never discussed and worked through, in an insight-oriented fashion, the patient appeared to view his first therapist who was a female, in a manner similar to his stance towards his mother. There was an ambivalence and a dichotomy of feelings related to fears of any criticism and judgement, as well as a longing for acceptance and love. The anger which stemmed from this ambivalence was manifested in the increased occurrence of violent fantasies and self-induced lacerations. This eventually led to the dissolution of his first therapeutic relationship because of fears for the safety of the therapist. The patient responded to this dissolution with feelings of rage secondary to feelings of rejection and abandonment.

Similarly, the patient appeared to relate to his second therapist in a manner suggestive of his relationship with his father. The emotional neutrality exhibited by his male therapist was somewhat akin to the emotional detachment of his father. Just as he idealized his father, he appeared to strive to follow any recommendations made by his therapist. Yet, just as he experienced no emotional fulfillment from his father and never grieved his father's loss, the patient seemed to guard against the development of any emotional investment in his relationship with his male therapist. Likewise, he never demonstrated any evidence of experiencing a "loss" at the termination of his second therapeutic relationship.

Of the feelings evoked in a therapist treating such a patient, anxiety may occur especially in the early stages of treatment, before there is a feeling of trust that the patient will not act out on his destructive impulses and fantasies. What is required to establish this trust is an understanding of the patient, including the ability to gauge the fluctuations in his relative emotional stability, with regard to the likelihood of his actually acting out destructively. Also required is the engenderment in the patient of a sense of trust in the therapist; trust that the therapist genuinely cares for him and that the therapist will not be overwhelmed by the patient's fears of loss of control.

Feelings of inadequacy can also develop in the therapist, as he sees such a patient's symptoms continue to escalate, despite earnest and considered psychotherapeutic interventions and aggressive psychopharmacologic management.

On the other hand, feelings of great satisfaction and accomplishment can occur, if and when one sees sustained improvement in the patient's condition; 
however, in order to achieve such an improvement, one must have an understanding of the borderline personality.

Much has been written on the borderline personality concerning the criteria for its diagnosis, its development according to psychoanalytic theory and its treatment. Perry and Klerman (2) in their review of diagnostic criteria based on the writings of Knight, Kernberg, Grinker, Gunderson, and Singer concluded that in borderline patients, "it seems as if the whole range of psychopathology of personality is represented." This is one likely reason that their treatment is so difficult. Another difficulty in treatment would appear to be due to the very source of the development of the disorder as theorized by Kernberg (3). He postulated that difficulties in the Mahlerian stage of separationindividuation during childhood lead to internalized object relations deficits, in that there is impairment of the essential task of the ego regarding differentiating self from external objects and integrating self and object under the influence of libidinal and aggressive derivatives. He states that this lack of integrated self concept and of the relationship of self with objects results in what Erikson called Identity Diffusion.

Buie and Adler (4) relate that the fundamental psychopathology in Borderline Personality involves annihilation anxiety as a consequence of inadequacy and instability of holding-soothing introjects, with an inability to internalize real caring relationships necessary for the development of these introjects. It would seem that these core developmental deficits are that which are in need of repair (or indeed which require establishment in the first place) in order to successfully treat the borderline patient. To effect this change via a therapeutic relationship requires a long and painstaking effort. Buie et al, proposed that treatment resulting in a mature level of emotional autonomy in these patients can be accomplished by a three phase approach: first, the therapist is established as a holding-soothing introject; later the patient becomes able to accept external objects with this same quality in a realistic and non-idealized way; and finally the patient develops a capacity for stable autonomy, self-security and sense of self-worth via identification with the therapist.

Gunderson (5), as well as Davis and Akiskal (6), have proposed that the borderline personality probably represents a heterogeneous disorder for which no single pharmacologic treatment seems uniformly effective, but for which various psychotropic agents, including both TCA and MAOI antidepressants, neuroleptics, anxiolytics and lithium have been employed (as well as no medication) depending on the presenting target symptom. Salzman (7) has listed borderline character as being a predictor of poor response to ECT. While ECT was associated with clinical improvement of depressive symptoms in this patient, it is unclear to what extent this association was causal.

Both establishment of diagnostic criteria for the identification of a distinct illness and having a theoretical and/or biochemical basis for the development of that illness are essential for the goal of being able to apply a specific effective treatment, be it of a psychotherapeutic or psychopharmacologic nature, or a 
combination of the two. Beyond that, however, is a recognition of the importance of an understanding of the variables of torment experienced and suffered by each individual patient.

The patient presented here, a young man who devised seemingly beastly acts in order to attain the goal of what amounted to sainthood, was tormented by, among other things, the struggle to find himself, a task which indeed we all face, as was so eloquently stated by the writer, J.L. Borges (8):

The story goes that Shakespeare found himself before God and he said, "I, who have been so many men in vain, want to be one man, myself." The voice of God responded from a whirlwind, "Neither am I oneself; I dreamed the world as you dreamed your work, my Shakespeare, and among the shapes of my dreams are you, who, like me, are many persons-and none."

\section{REFERENCES}

1. Donleavy JP: The Beastly Beatitudes of Balthazar B. Delacorte, 1968

2. Perry C, Klerman G: The borderline patient. Arch Gen Psychiatry 35:141-150, 1978

3. Kernberg O: Borderline Conditions and Pathological Narcissism. New York, J. Aronson, 1975

4. Buie D, Adler G: The definitive treatment of the borderline personality. Int $J$ Psychoanal Psychother 9:51-87, 1982

5. Gunderson J: The interface between borderline personality disorder and affective disorder. Am J Psychiatry 142:277-288, 1985

6. Davis G, Akiskal H: Descriptive, biological and theoretical aspects of borderline personality disorder. Hosp E Comm Psychiatry 37:685-692, 1986

7. Salzman C: Manual of Psychiatric Therapeutics. Edited by Shader R. Little, Brown \& Co., 1975, pp 115-124

8. Borges JL: Labyrinths. New Directions, 1969, pp 46-47 